\title{
ArcheoSciences
}

Revue d'archéométrie

$36 \mid 2012$

Varia

\section{Materials applied in Bernardo Martorell's painting analysed by portable XRF}

Matériaux employés dans une peinture de Bernardo Martorell analysée par XRF portable

Anabelle Kriznar, Maria del Valme Muñoz, Miguel Ángel Respaldiza and Mercedes Vega

\section{OpenEdition}

\section{Journals}

Electronic version

URL: https://journals.openedition.org/archeosciences/3712

DOI: 10.4000/archeosciences.3712

ISBN: 978-2-7535-2243-5

ISSN: 2104-3728

Publisher

Presses universitaires de Rennes

Printed version

Date of publication: 31 December 2012

Number of pages: $37-46$

ISBN: 978-2-7535-2241-1

ISSN: 1960-1360

\section{Electronic reference}

Anabelle Kriznar, Maria del Valme Muñoz, Miguel Ángel Respaldiza and Mercedes Vega, "Materials applied in Bernardo Martorell's painting analysed by portable XRF", ArcheoSciences [Online], 36 | 2012, Online since 31 December 2014, connection on 28 January 2022. URL: http://

journals.openedition.org/archeosciences/3712 ; DOI: https://doi.org/10.4000/archeosciences.3712

Article L.111-1 du Code de la propriété intellectuelle. 


\title{
Materials Applied in Bernardo Martorell's Painting Analysed by Portable XRF
}

\author{
Matériaux employés dans une peinture de Bernardo Martorell \\ analysée par XRF portable
}

\author{
Anabelle Kriznar*, Maria del Valme Muñoz**, \\ Miguel Ángel RespaldizA* and Mercedes VEGA**
}

\begin{abstract}
Bernardo Martorell was a leading artist of the $15^{\text {th }}$ century in Catalonia. His panel painting the Ascension of the Virgin is one of the oldest in the collection of Fine Arts Museum of Seville. This is why it was chosen for the analysis among several other panels which form part of a bigger project between the Museum and the National Centre of Accelerators. The research work is dedicated to the characterization of materials applied in the Spanish paintings in the $15^{\text {th }}$ and $16^{\text {th }}$ centuries. The painting was studied by non-destructive techniques (UV light and a portable $\mathrm{X}$-Ray fluorescence) to obtain information on materials applied and possible later interventions. The results showed that the original pigments applied are common for that period of time: lead white $(\mathrm{Pb})$ yellow and red ochres $(\mathrm{Fe})$, massicot, $(\mathrm{Pb})$, umbra $(\mathrm{Mn}, \mathrm{Fe})$, vermillion $(\mathrm{Hg})$, azurite $(\mathrm{Cu})$ and a copper based green pigment $(\mathrm{Cu})$. The thin layer of gold, confirmed by Au peaks, is applied over the surface, on top of a red bole layer. Some black areas over the gilded surface contain Ag. Retouches contain Ti, Zn, Cr and Cd that confirm the use of modern pigments, such as titanium-zinc white, chrome green or cadmium red.
\end{abstract}

Résumé : Bernardo Martorell fût un artiste phare du XV siècle en Catalogne. Sa peinture intitulée "L'Ascension de la Vierge " est une des plus anciennes constituant la collection du Musée des Beaux-arts de Séville. C'est la raison pour laquelle elle fût sélectionnée parmi un grand nombre d'autres peintures pour subir une série d'analyses sincorporant dans un vaste projet entre le Musée et le Centre National des Accélérateurs. Le travail de recherche fût consacré à la caractérisation des matériaux employés dans la peinture espagnole des XV et XVI siècles. Cette peinture fût étudiée via l'application de techniques non destructives, telles que la photographie sous lumière UV et l'utilisation d'un appareil portable de fluorescence de rayons X, de manière à obtenir des informations sur les matériaux employés et détecter les éventuelles interventions ultérieures. Les résultats montrent que les pigments originaux employés sont d'usage courant à cette époque: du blanc de plomb (Pb), des ocres jaunes et rouges (Fe), du massicot (Pb), de la terre d'ombre (Mn, Fe), du vermillon $(\mathrm{Hg})$, de l'azurite $(\mathrm{Cu})$ et un ou des pigments verts à base de cuivre (Cu). Une fine couche d'or, confirmée par la présence des pics de l'or (Au), est appliquée en surface, au-dessus d'une couche de bol rouge. Quelques zones noires présentes sur la surface dorée contiennent de l'argent (Ag). Des retouches montrent la présence de titane ( $\mathrm{Ti})$, de zinc $(\mathrm{Zn})$, de chrome $(\mathrm{Cr})$ et de cadmium (Cd) qui confirment l'usage de pigments modernes, comme le blanc de titane, le blanc de zinc, le vert oxyde de chrome ou le rouge de cadmium.

Keywords: Bernardo Martorell, $15^{\text {th }}$ century, panel painting, pigments, UV, XRF.

Mots clé : Bernat Martorell, XV siècle, peinture sur bois, pigments, UV, XRF.

\footnotetext{
* Centro Nacional de Aceleradores, Universidad de Sevilla, Avda. Thomas A. Edison 7, Parque tecnológico Cartuja '93, 41092 Seville, Spain.(akriznar@ us.es)( respaldiza@us.es)

** Museo de Bellas Artes de Sevilla, Plaza del Museo 9, 41001 Seville, Spain. mvalme.munoz@juntadeandalucia.es) (mmercedes.vega@juntadeandalucia.es)
}

rec. jul. 2011 ; acc. may 2012

ArCheoSCIEnCes, revue d'archéométrie, 36, 2012, p. 37-45 


\section{INTRODUCTION}

Bernardo Martorell was a Spanish artist, born in Sant Celoni in Catalonia (Northern Spain) in the beginning of the $15^{\text {th }}$ century. Little is known of his life prior to 1427 , though by the mid 15th century he was one of the leading artists of that geographic area. The majority of his artworks were wooden altarpieces; however he designed also stained glass and illuminated manuscripts. Not many of his works have survived until today. They are mostly conserved in different Spanish museums, but can also be found outside, like in Paris and Chicago. One of Martorell's panel paintings is held in the Fine Arts Museum of Seville. It represents the Ascension of the Virgin with the Virgin Mary surrounded by apostles and the kneeling Christ in the upper part of the composition (Figure 1). The panel is considered one of the oldest artworks in the Museum's collection, painted towards 1454. It came to the Museum from the Zayas Collection in Stanford (Connecticut, USA) as a donation of Madame

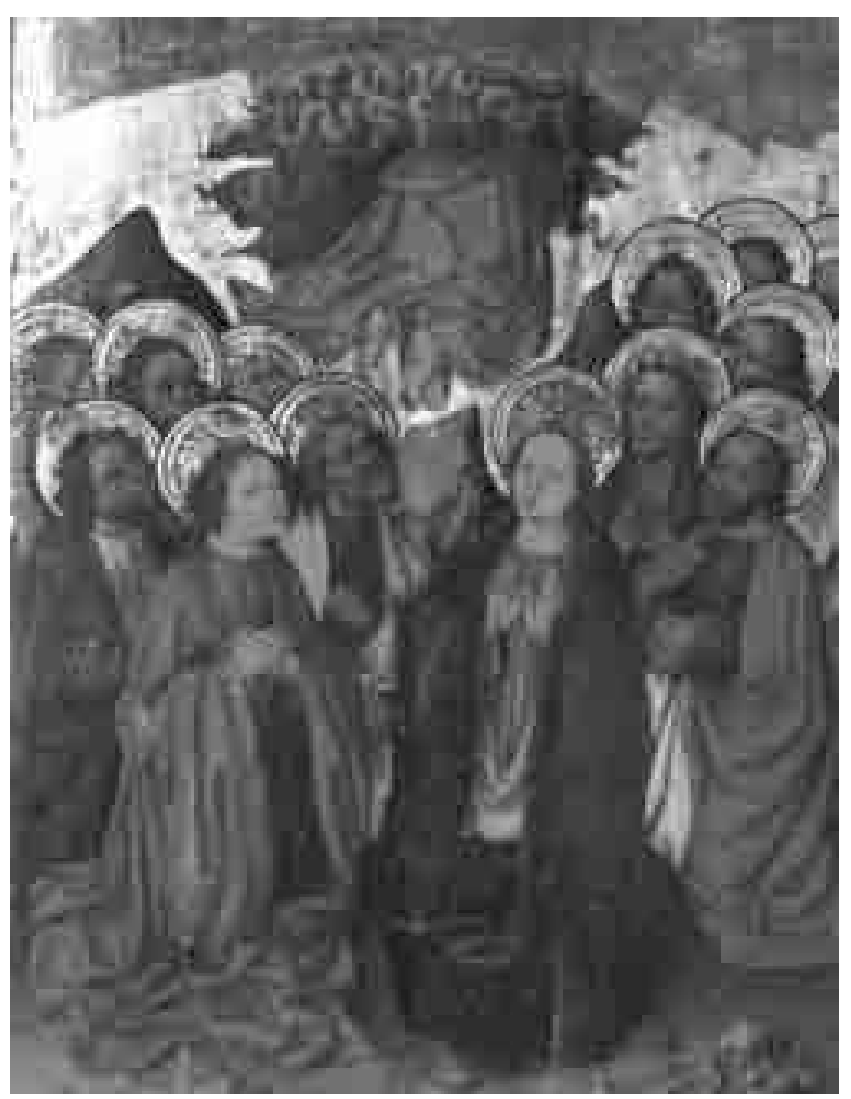

Figure 1: (See colour plate) Bernardo Martorell: Ascension of the Virgin (towards 1454). Fine Arts Museum of Seville.

Figure 1 : (Voir planche couleur) Bernat Martorell : Ascension de la Vierge (vers 1454). Musée des Beaux-Arts de Séville.
Virginia Harrison on the $3^{\text {rd }}$ of January of 1971 (Izquierdo \& Muñoz, 1990).

Due to its early date, it was chosen for the analysis in order to get more information on materials applied by the master: the preparation of the painting, the palette of the pigments, the formulation of shades and highlights and, where possible, the sequence of colour layers. The results would allow not only to understand better the artist and his painting procedures, but also to compare the information obtained in other paintings from the same artistic circle. The research work is part of a bigger project, dedicated to the characterization of Spanish painting in the $15^{\text {th }}$ and $16^{\text {th }}$ centuries, in collaboration between the Museum and the National Centre of Accelerators (University of Seville).

\section{Methods}

The analysis of Martorell's panel was carried out in situ in the Museum's store where it is temporarily held, without the necessity to move the artwork from its location. The painting was first studied by the naked eye which offered first information on several painting procedures and the construction of the work. For further research, non-destructive techniques were chosen. The panel was observed under the UV light to get more precise information about later interventions and retouches on the painting surface (Mairinger, 2000). For this, two pairs of $1 \mathrm{~m}$ high and $30 \mathrm{~cm}$ wide UV lamps were placed on each side of the painting to obtain the most homogeneous illumination of the surface (the bulbs are Philips TLD 36W/80). In some parts of the painting, also a pensize microscope camera Digitus with built-in bright LED light was applied in order to get magnifications (x10-x200) of some confusing areas.

Next, portable X-Ray fluorescence equipment was used to analyse the pigments and other materials applied in the panel (Fig. 2). Our XRF equipment consists of an EIS Company X-Ray generator RX38 and a silicon drift detector (SDD) of $140 \mathrm{eV}$ energy resolution. An Al filter of $1 \mathrm{~mm}$ thickness is added to the tube to suppress the $\mathrm{W}$ peaks of the anode. The diameter of the radiated spot is $3 \mathrm{~mm}$. Two lasers are coupled to the X-Ray tube in a fixed geometry, which allows a constant distance of approx. $5 \mathrm{~mm}$ between the tube and the painting surface. This arrangement makes possible the direct comparison among the obtained spectra of different points. The penetration depth of $\mathrm{X}$ rays varies depending on the density and type of the material analysed; it is normally in the order of a few tens of microns.

This technique is very useful in the non-destructive study of materials, especially in art. It allows the first exam of an 


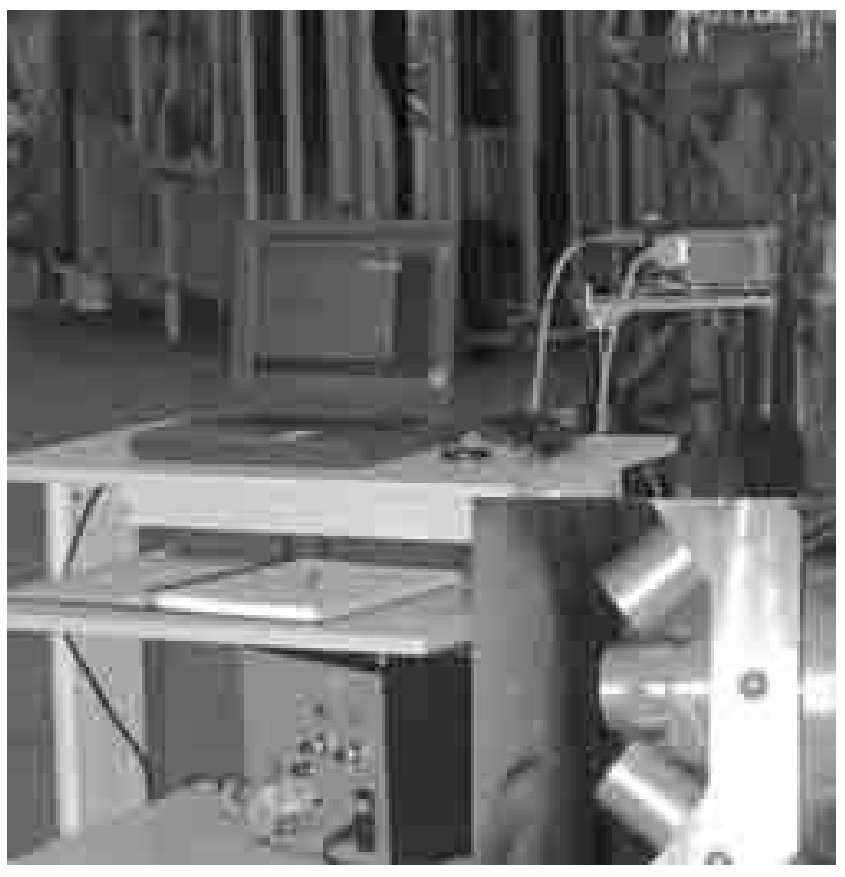

Figure 2: Analysis in situ by X-Ray Fluorescence.

Figure 2: Analyses in situ par fluorescence de rayons $X$.

artwork, identifying inorganic pigments applied by an artist. XRF gives elemental results, revealing chemical elements present in a radiated point, but not molecular compositions. This is why pigments characterized by the same chemical element like $\mathrm{Cu}$ based greens or $\mathrm{Pb}$ based pigments cannot be distinguished, which is a limitation of this technique. Also organic pigments or lapis lazuli cannot be identified; usual XRF systems do not detect elements with $Z$ lower than 13 or 14 (Volpin \& Appolonia, 2002; Deming Glinsman, 2004; Seccaroni \& Moioli, 2004). Therefore, in many cases, only a hypothesis on applied pigments can be given, based on the analysed colour and the knowledge on traditional painting techniques and materials. Some uncertain pigments could be identified by means of Raman spectroscopy, however most of the paintings analysed in situ are covered with a thick layer of varnish and no results are obtained, as it could have been proven in different occasions.

All paintings were measured under the same fixed conditions, which allowed the comparison among the results and a semi-quantitative analysis: $80 \mu \mathrm{A}$ of cathode current, $29.5 \mathrm{kV}$ of applied high voltage and 300s of preset live time. On the spectra $\mathrm{Zr}$ peaks from the collimator of the detector can appear, but these do not interfere with the results. In the painting 128 points were selected over the entire surface, trying to analyse different colours, tonalities, shades and highlights (Fig. 3). The pigments were identified accor-

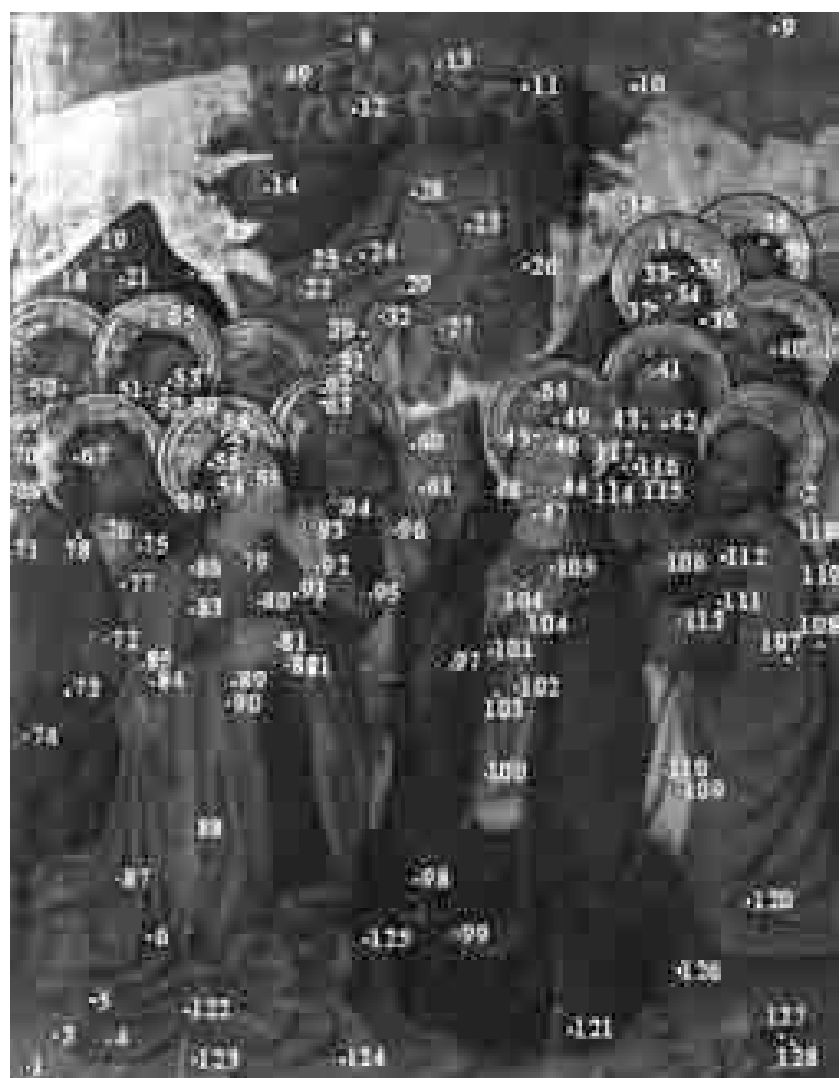

Figure 3: (See colour plate) Selected points, analysed by X-Ray Fluorescence.

Figure 3: (Voir planche couleur) Points sélectionnés, analyses par fluorescence de rayons $X$.

ding to the characteristic energy $(\mathrm{keV})$ of the X-ray peaks in each obtained spectrum, which correspond to specific chemical elements. (Gómez, 2000; Volpin \& Appolonia, 2002; Deming Glinsman, 2004; Matteini \& Moles, 2004; Seccaroni \& Moioli, 2004). In the results section, the characteristic elements for the different pigments are given in bracelets when they are mentioned.

\section{Results}

\section{Visual exam and UV light}

The painting is carried out on a gilded ground. In the upper part, once covered by a frame, only bole without gold can be observed. The visual exam discovered the use of incisions for different forms like the cloud around the Christ, the aureoles of the saints and their decoration, the lines of their heads, the folds of the Virgin's Mary blue coat, the Christ's tunic, or the rock in the centre of the painting. Such 
an abundant use of incisions reveals the use of stencils in the composition of this scene. For the decoration of aureoles also pouncing was applied, selecting tools of different forms. In the centre of some aureoles small hole can be observed, which shows the use of compass for the perfect circle. In several cases, a preparatory drawing can be distinguished as black lines under transparent colour layers, especially in Christ's, Saint John Evangelist's and Saint Peter's the vestments. It can be also observed that the final elaboration of the figures not always follows the original one, but it changes slightly.

The exam with UV light (Figure 4) shows several retouched areas that reveal later interventions. These can be observed especially on the panel's outer borders and on junctions of wooden panels. Images obtained under UV light helped at the selection of the points analysed by X-Ray Fluorescence.

\section{X-Ray Fluorescence}

As commented above, the painting was analysed in 128 points of different colours and tonalities. The most impor-

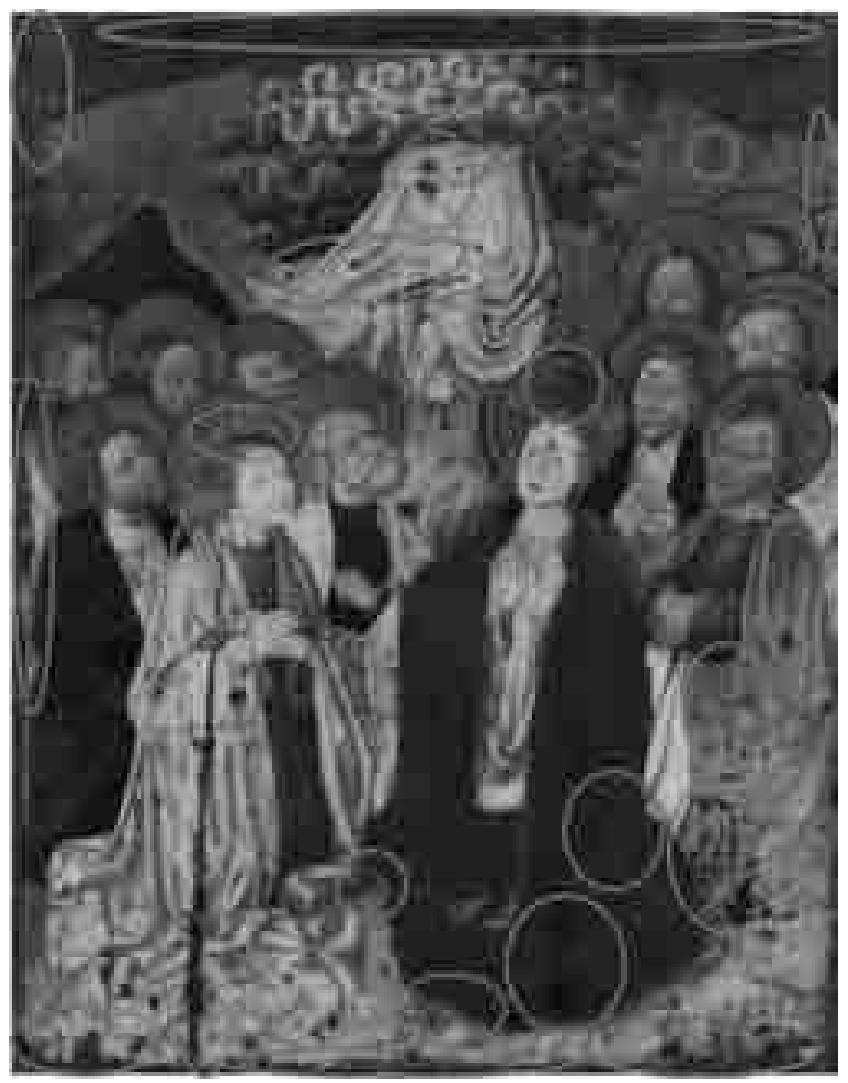

Figure 4: (See colour plate) Bernardo Martorell: Ascension of the Virgin. Under UV light. Visible later inteventions.

Figure 4: (Voir planche couleur) Bernat Martorell: Ascension de la Vierge. Sous lumière UV. Interventions tardives observables. tant chemicals elements detected by XRF are $\mathrm{Ca}, \mathrm{Fe}, \mathrm{Cu}$, $\mathrm{Hg}, \mathrm{Au}$ and $\mathrm{Pb}$, in some areas also $\mathrm{Al}, \mathrm{P}, \mathrm{K}, \mathrm{Mg}$ and $\mathrm{Ag}$ can be observed. As already explained, on the bases of these elements it was possible to identify the pigments or at least to make some hypothesis on the applied painting materials and the colour layer sequence. For more precise answer other techniques, especially destructive ones (elaboration of crosssections), should be used.

\section{Preparation}

The results showed that the painting is made on a calcium preparation, which could be calcium carbonate $\left(\mathrm{CaCO}_{3}\right)$ or sulphate $\left(\mathrm{CaSO}_{4}\right)$. In all spectra an important presence of $\mathrm{Ca}$ can be observed, however with XRF it is not possible to distinguish between different chemical compounds, as explained above. Nevertheless, in Martorell's case the preparation is probably made of gypsum, which was mainly used as a preparation ground in Southern Europe (Gómez, 2000; Townsend, 2008). It would be possible to confirm the use of gypsum on the bases of $\mathrm{Ca}$ and $\mathrm{S}$ presence, but due to high presence of lead compounds in these paintings, $S \mathrm{~K} \alpha$ peaks are covered by $\mathrm{Pb} \mathrm{M} \alpha$ peaks and therefore not visible. Therefore, only calcium can be confirmed. In some cases where $\mathrm{Ca}$ count numbers are much higher in comparison to other analysed points, this chemical element is probably present also in the pigment applied in that area, as explained further on.

Another important element, present in every analysed point, is $\mathrm{Pb}$. As with $\mathrm{Ca}$ compounds, also with $\mathrm{Pb}$ ones the XRF technique cannot determine the material used, that is, it can not be distinguished between lead white $\left(\mathrm{PbCO}_{3}\right)$, yellow litharge or massicot $(\mathrm{PbO})$ or orangered minium $\left(\mathrm{Pb}_{3} \mathrm{O}_{4}\right)$ (Schram, 1995; Volpin \& Appolonia 2002; Seccaroni, Moioli, 2004). It could also not be determined with precision in which painting layer(s) the $\mathrm{Pb}$ can be found. Its individual net peak area count numbers vary importantly depending on the colour analysed, showing the application of lead pigments. However, its presence (even at very low count rates) in every analysed point shows that it must be applied over the entire surface. There is, hence, probably a $\mathrm{Pb}$ based imprimation applied, made of lead white or minium. Having in mind that the painting technique of this panel is oil, lead compounds could have been used also as a dryer for the binder. Therefore, the lead compounds were probably used in three different ways as: (a) pigment), (b) imprimation and (c) dryer.

\section{Pigments}

The original pigments applied are common for that period of time (Wehlte, 1967; Doerner, 1984; West Fitzhugh et al., 
1987-2007; Knoepfli et al., 1990; Montagna, 1993; Schram 1995; Brachert, 2001; Eastaugh et al., 2008): lead white (identified on the spectra through the characteristic lines of $\mathrm{Pb})$, yellow and red ochres $(\mathrm{Fe})$, massicot, $(\mathrm{Pb})$, umbra $(\mathrm{Mn}$, $\mathrm{Fe})$, vermillion $(\mathrm{Hg})$, azurite $(\mathrm{Cu})$ and a copper based green pigment $(\mathrm{Cu})$ (Table 1$)$. They are mostly used in combination with others from the pallette, as it is explained further on, in order to obtain the desired colour or tonality. The highlights were carried out with lead white, pure or added to the basic colour, while the shades by a mixture of ochre or umbra, copper based green pigment and probably an organic red or black. Probably also organic red and black pigments were used, which can not be confirmed by XRF due to the low $\mathrm{Z}$ number of characteristic chemical elements. White colour. The pigment applied was lead white $\left(\mathrm{PbCO}_{3}\right)$, characterized by high $\mathrm{Pb}$ peaks in white areas. The shades of white vestments were carried out as a mixture of azurite $(\mathrm{Cu})$, ochre $(\mathrm{Fe})$ and sometimes umber $(\mathrm{Mn}, \mathrm{Fe})$. Probably also an organic black was added for the darkest folds. Lead white was applied also to lighten darker pigments and for highlights, as well as the principle pigment for carnations.

Carnations. Faces, hands and feet were carried out with small amount of ochre (Fe), a copper based green pigment $(\mathrm{Cu})$ and vermilion $(\mathrm{Hg})$, mixed with lead white (Fig. 5). The proportion of applied pigments, shown by lower or higher peak intensity, varies depending on lighter or darker tonality. In lighter areas, $\mathrm{Pb}$ peaks are the highest, confirmed also with high $\mathrm{Pb}$ count numbers (up to 830 counts per second or $\mathrm{cps}$ ), while in other areas $\mathrm{Pb}$ count numbers are lower and those of $\mathrm{Hg}, \mathrm{Fe}$ or $\mathrm{Cu}$ grow. For example, there is a higher amount of vermilion present in areas of reddish tonality like cheeks, confirmed by higher $\mathrm{Hg}$ count numbers

\begin{tabular}{|c|c|c|c|c|}
\hline & Spotnum bers & $\begin{array}{l}\text { Major*,m inor**a nd } \\
\text { trace (tr) elements } \\
\text { detected }\end{array}$ & Pigmentsa pplied & Chemicalc omposition \\
\hline WHITE & $92,93,96,118,119$ & $\mathrm{~Pb}^{*} ; \mathrm{Fe}, \mathrm{Sr}^{* *} ; \mathrm{Ca}, \mathrm{Cu}(\mathrm{tr})$ & lead white $(\mathrm{Pb})$ & $\mathrm{PbCO}_{3}$ \\
\hline CARNATIONS & $\begin{array}{l}31-33,34,37,41-47 \\
50-52,54,55,75,81,82 \\
95,104,105,113\end{array}$ & $\begin{array}{l}\mathrm{Pb}, \mathrm{Hg}, \mathrm{Fe}^{*} ; \mathrm{Sr}^{* *} ; \mathrm{Ca} \\
\mathrm{Mn}, \mathrm{Cu}(\mathrm{tr})\end{array}$ & $\begin{array}{l}\text { lead white }(\mathrm{Pb})+\text { vermi- } \\
\text { lion }(\mathrm{Hg})+\text { ochre }(\mathrm{Fe}) / \\
\text { umber }(\mathrm{Mn}, \mathrm{Fe})\end{array}$ & $\begin{array}{l}\mathrm{PbCO}_{3} \\
\mathrm{HgS} \\
\mathrm{Fe}(\mathrm{OH})_{2} \\
\mathrm{Fe}_{2} \mathrm{O}_{3}+\mathrm{MnO}_{2}\end{array}$ \\
\hline YELLOW & $76,77,100,101$ & $\begin{array}{l}\mathrm{Pb}, \mathrm{Fe}^{*} ; \mathrm{Sr}, \mathrm{Cu}^{* *}, \mathrm{Ca} \\
\mathrm{Hg}(\mathrm{tr})\end{array}$ & $\begin{array}{l}\text { yellow ochre }(\mathrm{Fe}) \text {, massi- } \\
\text { cot }(\mathrm{Pb}) \text { ? }\end{array}$ & $\begin{array}{l}\mathrm{Fe}(\mathrm{OH})_{2} \\
\mathrm{PbO}\end{array}$ \\
\hline RED & $7-10,49,106-110,120$ & $\begin{array}{l}\mathrm{Hg}, \mathrm{Fe}^{*} ; \mathrm{Pb}, \mathrm{Ca}, \mathrm{Sr}^{* *} ; \\
\mathrm{Cu}(\mathrm{tr})\end{array}$ & $\begin{array}{l}\text { vermilion }(\mathrm{Hg})+\text { red } \\
\text { ochre }(\mathrm{Fe}) \\
+ \text { organic red }(\mathrm{Ca}) ?\end{array}$ & $\begin{array}{l}\mathrm{HgS} \\
\mathrm{Fe}_{2} \mathrm{O}_{3}\end{array}$ \\
\hline PINK & $\begin{array}{l}4-6,22-29,68-71,83-91 \\
102,103,115-117\end{array}$ & $\begin{array}{l}\mathrm{Pb}^{*} ; \mathrm{Hg}, \mathrm{Fe}, \mathrm{Cu}^{* *} ; \mathrm{K}, \\
\mathrm{Ca}(\mathrm{tr})\end{array}$ & $\begin{array}{l}\text { lead white }(\mathrm{Pb})+ \\
\text { vermilion }(\mathrm{Hg})+\text { red } \\
\text { ochre }(\mathrm{Fe}) * \\
\text { organic red }(\mathrm{Ca}) \text { ? }\end{array}$ & $\begin{array}{l}\mathrm{PbCO}_{3} \\
\mathrm{HgS} \\
\mathrm{Fe}(\mathrm{OH})_{2} \\
(\mathrm{~K}, \mathrm{C} \mathrm{a})^{2}\end{array}$ \\
\hline BLUE & $\begin{array}{l}11-14,79,80,97-99 \\
111,112,121\end{array}$ & $\begin{array}{l}\mathrm{Cu}, \mathrm{Pb}^{*} ; \mathrm{Fe}, \mathrm{Sr}^{* *}, \mathrm{Ca}, \\
\mathrm{Hg}(\mathrm{tr})\end{array}$ & azurite $(\mathrm{Cu})$ & $2 \mathrm{CuCO} \cdot \mathrm{Cu}(\mathrm{OH})_{2}$ \\
\hline GREEN & $18-21,72-74,78,94,114$ & $\begin{array}{l}\mathrm{Cu}, \mathrm{Pb}^{*} ; \mathrm{Fe}, \mathrm{Sr}^{* *} ; \mathrm{Ca}, \\
\mathrm{Mn}(\mathrm{tr})\end{array}$ & $\mathrm{Cu}$ based green pigment & several posibilities \\
\hline BROWN & $\begin{array}{l}1,3,35,36,56,57,60 \\
61,66,67,123-128\end{array}$ & $\begin{array}{l}\mathrm{Fe}^{*} ; \mathrm{Pb}, \mathrm{Sr}^{* *} ; \mathrm{Ca}, \mathrm{Mn}, \\
\mathrm{Cu}, \mathrm{Hg}(\mathrm{tr})\end{array}$ & $\begin{array}{l}\text { ochre }(\mathrm{Fe})+\text { umber }(\mathrm{Mn} \text {, } \\
\mathrm{Fe})\end{array}$ & $\begin{array}{l}\mathrm{Fe}(\mathrm{OH})_{2} \\
\mathrm{Fe}_{2} \mathrm{O}_{3}+\mathrm{MnO}_{2}\end{array}$ \\
\hline BLACK & $2,20,127$ & $\mathrm{~Pb}^{*}, \mathrm{Fe}, \mathrm{Ca}^{* *}, \mathrm{~K}, \mathrm{Cu}(\mathrm{tr})$ & $\begin{array}{l}\text { Plant or animal black } \\
\text { pigment }\end{array}$ & complexf ormulas \\
\hline INTERVENTIONS & $\begin{array}{l}1,3,5,6,19,28,29, \\
34-36,46,56-58,60,61, \\
70,88,90-92,93,76-78, \\
100,101,120-128\end{array}$ & $\begin{array}{l}\mathrm{Zn}, \mathrm{Fe}, \mathrm{Ca}^{*} ; \mathrm{Ti}^{* *} ; \mathrm{Cr}, \\
\mathrm{Cd}(\mathrm{tr})\end{array}$ & $\begin{array}{l}\text { zinc white }(\mathrm{Zn})+\text { tita- } \\
\text { nium white }(\mathrm{Ti})+(\mathrm{Cr}) \\
\text { and }(\mathrm{Cd}) \text { based pigments }\end{array}$ & $\begin{array}{l}\mathrm{ZnO} \\
\mathrm{TiO}_{2} \\
\text { different formulas for } \mathrm{Cr} \\
\text { and Cd pigments }\end{array}$ \\
\hline
\end{tabular}

Table 1: The table is representing the major, minor and trace elements found in different colours on the panel painting, related to principle pigments applied (with its chemical composition).

Tableau 1 : Présentation des éléments majeurs, mineurs et traces détectés dans différentes couleurs de la peinture sur bois, associés aux principaux pigments employés (accompagnés de leur formule chimique). 


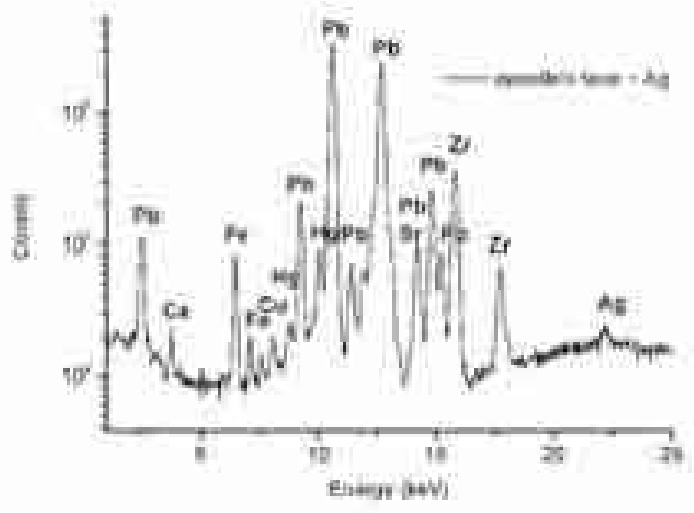

Figure 5: XRF spectrum of apostle's carnation. Peaks of $\mathrm{Fe}, \mathrm{Cu}$, $\mathrm{Hg}$ and $\mathrm{Pb}$ show the use of an ochre, copper based green pigment, vermilion and lead white. Also Ag is present.

Figure 5 : Spectre XRF de la carnation de l'apôtre. Les pics de $\mathrm{Fe}, \mathrm{Cu}$, $\mathrm{Hg}$ et $\mathrm{Pb}$ montrent l'utilisation d'une ocre, d'un pigment vert à base de cuivre, de vermillon et de blanc de plomb. Ag est aussi présent.

(30 cps in comparison to $4 \mathrm{cps}$ in whiter areas). Shades were carried out with a mixture of ochre $(\mathrm{Fe})$, umber $(\mathrm{Mn}, \mathrm{Fe})$ and a copper based green pigment $(\mathrm{Cu})$ whose individual count numbers vary depending on the tonality. Lips were painted by vermilion, and modelled with red ochre. Eyes were mostly carried out with ochre, only for principal figures like Virgin Mary and St. John Evangelist blue azurite was chosen $(\mathrm{Cu})$.

Yellow colour. It was analysed on the tunic of one of the apostles and in Virgin Mary's coat. Relatively high Fe numbers (12 cps) show that the principal pigment is yellow ochre $\left(\mathrm{Fe}(\mathrm{OH})_{2}\right)$, mixed with a lead based pigment, probably lead white. Iron count numbers are higher in darker areas (18 cps) showing higher amount of this pigment, while the amount of $\mathrm{Pb}$ is lower as in darker areas $(217 \mathrm{cps})$ than in lighter ones (337 cps), as expected. It would also be possible that for the light yellow colour the painter used massicot $(\mathrm{PbO})$, but by XRF it can not be distinguished from lead white due to the same characteristic chemical element.

Pink and red colours. Pink vestments like St. John Evangelist's coat or one of the apostle's tunic are painted with a mixture of lead white $(\mathrm{Pb})$, small amount of vermilion $(\mathrm{Hg})$ and ochre $(\mathrm{Fe})$. Their individual count numbers vary depending on lighter or darker tonality. Shades were carried out with ochre, as observed by high Fe peaks on the spectra obtained in darker areas, such as folds. For red colour, especially vermilion $(\mathrm{HgS})$ was applied, identified with very high count numbers in the red apostle's coat (163 cps), the red ribbon in Virgin Mary's hair (434 cps) or blood in Christ's feet (454 cps). In lower quantity it was used for carnations and pink vestments, as explained above. Another red pigment used by Bernardo Martorell was red ochre $\left(\mathrm{Fe}_{2} \mathrm{O}_{3}\right)$, a clay material, which contains iron oxides. It can not be directly identified as red ochre by XRF, because all ochres have $\mathrm{Fe}$ as the characteristic chemical element. But in this concrete case where the analysed colour is red, it can be determined that the painter applied red ochre especially for darker tonalities and for modelling of the shades. A possible third red colorant applied could be an organic lake. Being an organic material, it can not be identified directly by XRF, as explained above, however its presence can be suspected indirectly. In some darker areas higher Ca peaks are observed which could belong to a $\mathrm{CaCO}_{3}$ substrate for a liquid organic red lake. Also $\mathrm{K}$ peaks are visible in some spectra of red and pink areas, which normally identify the use of colorants made from plants.

Blue colour. High Cu peaks (from 185 cps to $842 \mathrm{cps}$ ) in all blue areas like several apostle's tunics, Virgin Mary's coat or the cloud that covers Christ, identify that the pigment applied is azurite $\left(2 \mathrm{CuCO} \bullet \mathrm{Cu}(\mathrm{OH})_{2}\right)$. It is mixed with lead white, whose proportion and therefore $\mathrm{Pb}$ count numbers depend on a lighter or darker tonality. In the spectra obtained in Virgin Mary's coat or in St. Peter's tunic, also relatively high Fe peaks can be observed (up to $8 \mathrm{cps}$ ), which reveals that there is probably an ochre layer under the azurite one (Fig. 6). The underlying of the azurite with ochre was a common procedure, which gave more intensity to the blue colour and at the same time allowed the painter to use a

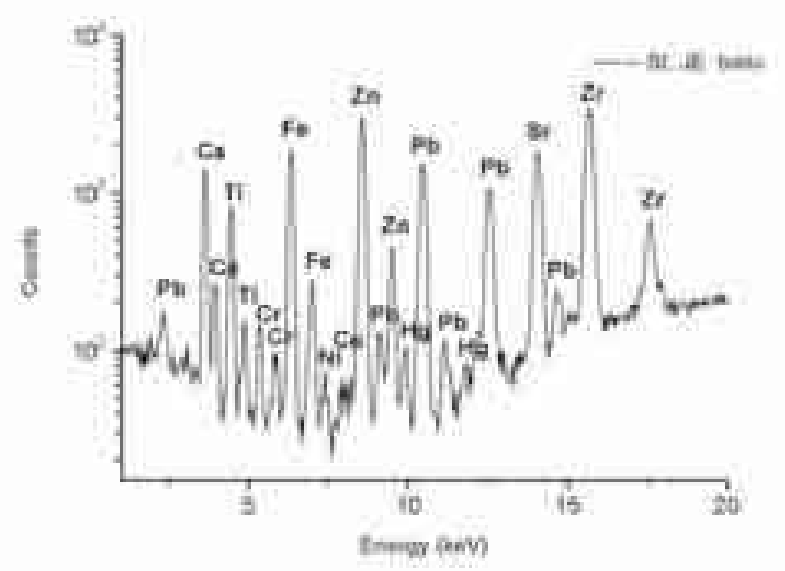

Figure 6: XRF spectrum of St. Peter's blue tunic. High $\mathrm{Cu}$ peaks identify blue pigment as azurite. The presence of Fe shows a possible ochre under-layer.

Figure 6: Spectre XRF de la tunique bleue de St. Pierre. Un pigment bleu comme l'azurite est identifiable par la présence de pics élevés de Cu. La présence de Fe montre une possible sous-couche à base d'ocre. 
smaller amount of the expensive mineral (Wehlte, 1967; Knoepfli et al., 1990; Brachert, 2001). On the other hand, Fe could also identify the existence of bole under azurite, showing in this way that the panel was maybe entirely covered by bole as a preparation for gold.

Green pigment. The characteristic chemical element obtained from apostle's green coat or the mountain in the background is $\mathrm{Cu}$ that identifies the pigments as a copper based one. There are many green pigments characterized by this chemical element, so by XRF it can not be determined more precisely which pigment was chosen. However, in the $15^{\text {th }}$ century the most common pigments were malachite $\left(\mathrm{CuCO}_{3} \cdot \mathrm{Cu}(\mathrm{OH})_{2}\right)$, verdigris $\left(\mathrm{Cu}\left(\mathrm{CH}_{3} \mathrm{COO}\right)_{2} \cdot 2 \mathrm{H}_{2} \mathrm{O}\right)$ or a copper based resinate $\left(\mathrm{Cu}\left(\mathrm{C}_{19} \mathrm{H}_{29} \mathrm{COO}\right)_{2}\right)$ (West Fitzhugh et al., 1987-2007; Knoepfli et al., 1990; Montagna, 1993; Eastaugh et al., 2008), so the pigment applied by Martorell is one of those. Lighter tonalities were obtained by adding lead white $(\mathrm{Pb})$ and darker ones by adding ochre $(\mathrm{Fe})$ or probably an organic black pigment. In some spectra low $\mathrm{K}$ peaks can be observed, which are characteristic for plant's substances.

Brown colour. Spectra of points selected in brown colour of hair, beards and the soil show high Fe peaks (up to $17 \mathrm{cps}$ ), identifying the pigment applied as ochre. In some areas also $\mathrm{Mn}$ was detected, revealing the use of umber $\left(\mathrm{Fe}_{2} \mathrm{O}_{3}+\right.$ $\mathrm{MnO}_{2}$ ) for darker tonalities. The presence of a copper based green pigment in greenish soil is very low (up to 2,4 cps). It is possible that for the darkest tonalities also an organic black pigment was applied.

Black colour. Almost all black pigments generally used in painting are of organic provenience and, therefore, impossible to identify by XRF due to the low $\mathrm{Z}$ number of their characteristic chemical elements (Seccaroni \& Moioli, 2004). However, in some cases a hypothetic existence of one of these pigments can be established. For example, the presence of $\mathrm{K}$ and Ca peaks in dark or black areas can point toward the use of a pigment of plant (for example vine black) or animal origin (bone black), respectively. The use of bone black could be confirmed by the presence of $\mathrm{P}$, but its $\mathrm{Z}$ number is very low and it is difficult to observe it on the XRF spectra.

\section{Golda ndsil ver}

A thin layer of gold, confirmed by high Au peaks (up to $82 \mathrm{cps}$ ), is applied over the surface and used also for saint's aureoles. It is not clear if the entire panel was gilded or only its upper part. Individual count numbers for Au vary depending on the thickness of the gold layer and its preservation.
The thickest layer was found on the St. John Evangelist's nimbus, where the Au count numbers are the highest in comparison to other analysed gilded areas. Golden leafs were laid on a red bole, observed in several areas, especially in the upper part of the panel that once was covered by a frame. Bole, clay reach in iron oxides, is confirmed with high $\mathrm{Fe}$ peaks in all these areas (up to $25 \mathrm{cps}$ ). In all analysed gilded points $\mathrm{Pb}$ peaks can be observed (around $35 \mathrm{cps}$ ) that are very low in comparison to polichromed areas of the panel painting, due to the attenuation effect of the gold and to the lack of lead pigments in this area. A lead based substance is applied only as an imprimation layer under the bole. On the other hand, Ca peaks are high (around $16 \mathrm{cps)}$ ), originating in a calcium based preparation (probably gypsum), as explained above.

Already by the naked eye some black patches can be observed on the gilded background as well as on the upper part of the painting covered by bole. XRF analysis confirmed the presence of $\mathrm{Ag}$, indicating that a silver foil was applied on the panel as well (Fig. 6). This chemical element was spotted also in some other isolated polichromed areas as kind of a silver dust. Several pictures by a digital microscope were taken in order to magnify the image, which would help to understand the position of silver towards the gold and the colour layers. In several images of small cracks and lacunas it can be observed that the silver foil was applied under the golden one, then the colour layers were overlaid (Fig. 7). The areas are so small that can not be analysed separately by $\mathrm{XRF}$ to confirm the sequence of the layers. In areas where only silver dust can be observed, silver probably suffered

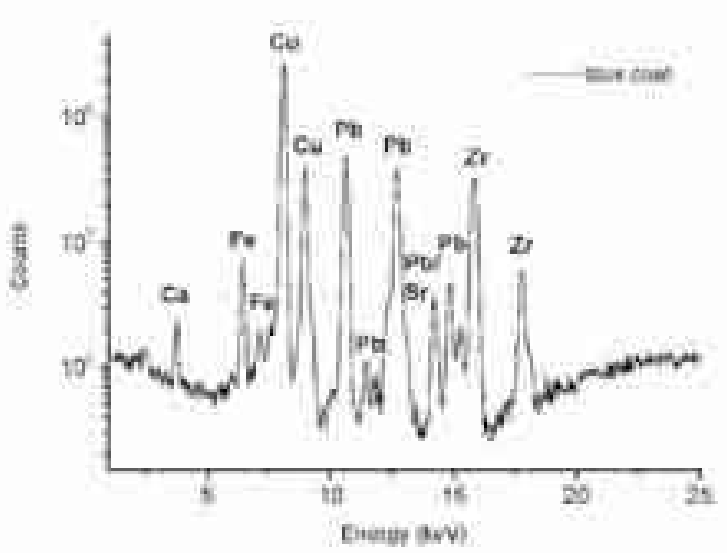

Figure 7: Image by a digital microscope of an apostles' face detail. Under the damaged colour layer of carnation, first a layer of gold and then a dark layer of silver can be observed.

Figure 7 : Détail du visage de l'apôtre obtenue avec un microscope digital. Sous la couche colorée de la carnation, on peut observer une couche dorée et ensuite une couche noire à base d'argent. 
some kind of chemical reaction that caused irruptions and damages in the colour layer (Fig. 8). It is possible that we are dealing with an example of the use of zwischgold, where one side of the foil is made of silver and the other of gold which makes it cheaper, but it is less stable (Knoepfli et al., 1993; Billinge et al., 1997). We tried to confirm the existence of the silver foil in the entire surface of the painting by analysing additional 55 carefully selected points over the entire surface. However, not in all spectra Ag peaks appear. This could be also due to the attenuation factor of gold and colour layers. The presence of a silver foil on the entire panel surface remains a hypothesis for now and it could be confirmed only by cross-sectional studies. It is also possible that silver foil applied in the upper border of the panel painting, where the darkest and largest black areas can be observed, was part of some later intervention.

\section{Interventions}

In some areas, retouches can be observed already by the naked eye. More precise situation is given by the UV image (Fig. 4). Results obtained by XRF reveal a presence of $\mathrm{Ti}$ and $\mathrm{Zn}$ in almost every analysed point, showing many small retouches on the bases of modern lead and zinc white pigments (Fig. 9). In these areas also $\mathrm{Ca}$ and Fe count numbers grow, indicating a mixture of these modern white pigments with some earth ones. In several areas also $\mathrm{Cr}$ and $\mathrm{Cd}$ were detected, revealing the use of chrome and cadmium based

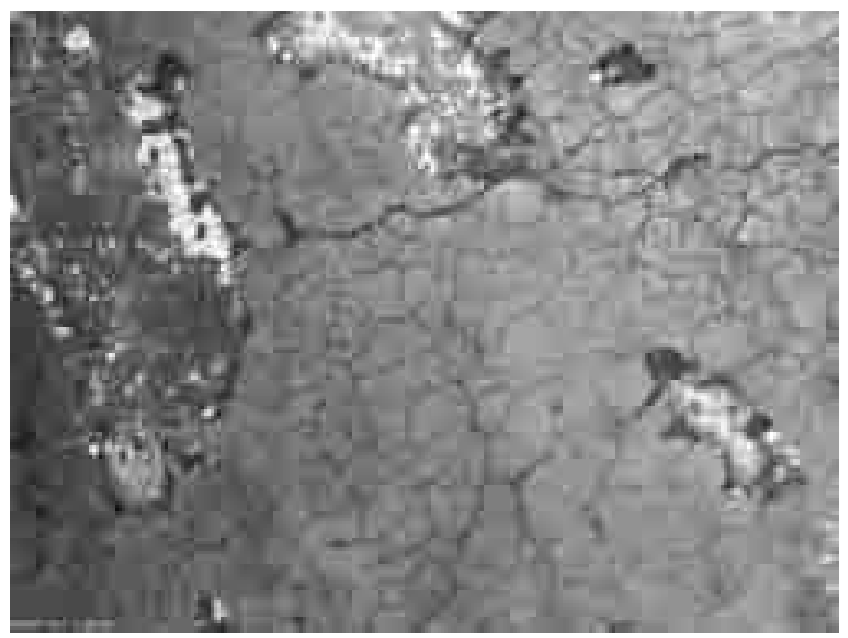

Figure 8: (See colour plate) Image by a digital microscope of St. John Evangelist's face detail, showing small brilliant areas irrupting through the colour layer. XRF analysis confirmed the presence of Ag. Figure 8: (Voir planche couleur) Détail du visage de l'Evangéliste St. Jean obtenue avec un microscope digital, montrant de petites zones brillants à travers la couche colorée. Les analyses XRF confirment la présence d'Ag.

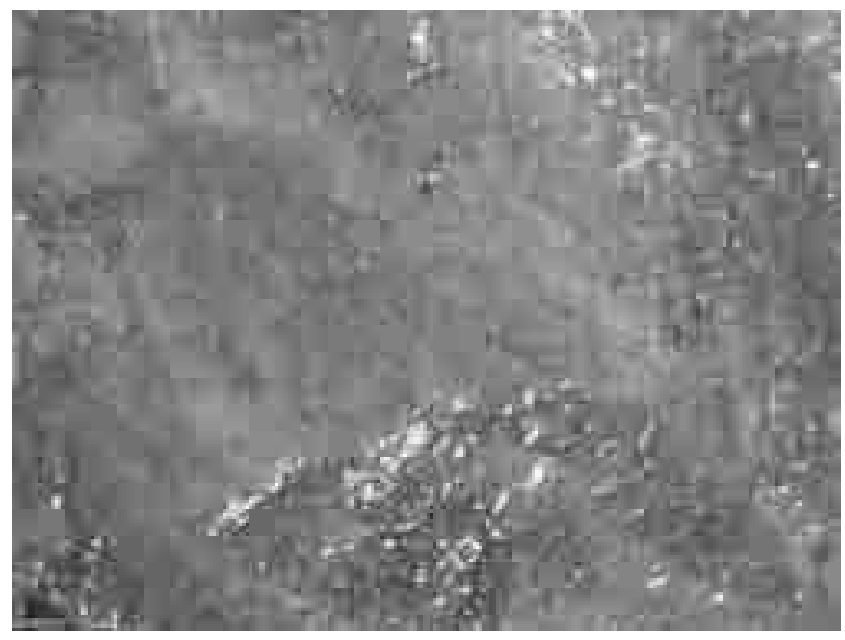

Figure 9: (See colour plate) XRF spectrum of St. John Evangelist's tunic. High $\mathrm{Ti}, \mathrm{Cr}$ and $\mathrm{Zn}$ peaks reveal later interventions with titanium and zinc whites.

Figure 9: (Voir planche couleur) Spectre XRF de la tunique de St. Jean l'Évangéliste. Des interventions tardives avec du blanc de titane et du blanc de zinc sont révélées par la présence de pics intenses de Ti, Cr et $Z n$.

pigments. As commented in the previous paragraph, a part of the silver foil found on the upper border of the painting can also belong to a later intervention and not to the original Martorell's work.

\section{Conclusions}

A non-destructive analysis of the panel painting The Ascension of the Virgin by Bernardo Martorell (1454) from the Fine Arts Museum in Seville was carried out in order to obtain more information on materials applied. The panel was examed with UV light, with a digital microscope and by X-Ray Fluorescence. Results showed that the painting is made on a calcium preparation, probably gypsum (calcium sulphate), on top of which a $\mathrm{Pb}$ based imprimation was laid. The pigments applied were typical for that period of time: lead white, $(\mathrm{Pb})$ yellow and red ochres $(\mathrm{Fe})$, umber $(\mathrm{Mn}$, $\mathrm{Fe})$, vermillion $(\mathrm{Hg})$, azurite $(\mathrm{Cu})$ and a copper based green pigment $(\mathrm{Cu})$. Probably also organic red and black pigments were used, which can not be confirmed by XRF. These pigments were mixed in different combinations, in order to obtain the desired colour or tonality. A thin layer of gold, confirmed by Au peaks, is applied over the entire surface, on top of a red bole layer. Some black areas observed were confirmed to contain Ag. This element was detected also in several degraded areas of the painting, which points towards 
the hypothesis of a silver foil under the golden one. Many retouched areas can be observed already under the UV light, which were confirmed by XRF as containing modern $\mathrm{Ti}$, $\mathrm{Zn}, \mathrm{Cr}$ and $\mathrm{Cd}$ pigments. This research is a part of a wider interdisciplinary work dedicated to the characterization of materials applied in the Spanish paintings in the $15^{\text {th }}$ and $16^{\text {th }}$ cent uries.

\section{Acknowledgements}

We acknowledge the financial support from the Projects of Excellence 205/HUM-493 and HUM 04544 of Junta de Andalucía, as well as a post-doctoral contract Juan de la Cierva of the Spanish Ministry of Science and Innovation.

\section{References}

Bazzi, M., 1993 - Abecedario pittorico. Neri Pozza, Vicenca.

Billinge, R., Campbell, L., Dunkerton, J., Foister, S., Kirby, J., Pilc, J., Roy, A., Spring, M. and White, R., 1997 Methods and materials of Northern European Painting in the National Gallery, National Gallery Technical Bulletin, Vol. 21, London.

Brachert, T., 2001. Lexikon historischer Maltechniken: QuellenHandwerk - Technologie - Alchemie. Callwey Verlag, München.

Deming Glinsman L., 2004 - The Application of X-Ray Fluorescence Spectrometry to the Study of Museum Objects. University of Amsterdam, Amsterdam.

Doerner, M., 1984 - The materials of the artists and their use in painting, with notes on the techniques of the old masters. A Harvest Book, Harcourt, Inc., San Diego, New York, London. Eastaugh, N., Walsh, V., Chaplin, T., and Siddall, R. (eds.), 2008 - Pigment Compendium, a dictionary and optical microscopy of historical pigments. Elsevier, Amsterdam, Boston,
Heidelberg, London, New York, Oxford, Paris, San Diego, San Francisco, Singapore, Sydney, Tokyo.

Gómez, M. L., 2000 - Exámen científico aplicado a la conservación de obras de arte. Cátedra, Instituto del patrimonio histórico español, Madrid.

Izquierdo and R., Muñoz, V., 1990 - Museo de Bellas Artes, Inventario de pintura, $\mathrm{G}$ rafiberica, Sevilla.

Knoepfli, A., Emmenegger, O., Koller, M., and Meyer, A. (eds.), 1990 - Reclams Handbuch der künstlerischen Techniken. Philipp Reclam jun., Stuttgart.

Mairinger, F., 2000 - The ultraviolet and fluorescence study of paintings in manuscripts. Creagh, D. C., Bradley, D. A. (eds.) - Radiation in Art and Archeometry. Elsevier. Amsterdam, Lausanne, New York, Oxford, Shannon, Singapore, Tokyo.

Matteini, M. and Moles, A., 2004 - La chimica nel restauro: I materiali dell'arte pittorica. Nardini editore, Firenze.

Montanga, G., 1993 - I pigmenti, Prontuario per l'arte e il restauro. Nardini editore, Firenze.

Seccaroni, C. and Moioli, P., 2004 - Fluorescenza X: Prontuario per l'analisi XRF portatile applicata a superfici policrome. Nardini editore, Firenze.

Schram, H. P. and Herling, B., 1995 - Historische Malmaterialen und ihre Identifizierung. Ravensburg Buchverlag, Stuttgart.

Townsend, J. H., Doherty, T., Heydenreich, G., and Ridge, J. (eds.), 2008 - Preparation for painting, the artist's choice and its consequences. Archetype Publications, London.

Volpin, S. and Appolonia, L., 2002 - Le análisis di laboratorio aplicate ai beni artistici policromi. Il Prato, Padova.

Wehlte, K., 1967 - Werkstoffe und Techniken der Malerei. Otto Maier Verlag, Ravensburg.

West Fitzhugh, E., Feller, R.L., Roy, A., and Berrie, B. (eds.), 1987-2007 - Artists' pigments: A Handbook of their history and characterisation. National Gallery of Art, Oxford University Press, Washington, New York, Oxford. 